\title{
The Impact of Divorce on Children in the Civil Law Perspective
}

\author{
Ridwan Syaidi ${ }^{1}$, Zudan Arief Fakrulloh ${ }^{2}$ \\ \{syaidi.ridwan@gmail.com ${ }^{1}$, cclsis@yahoo.com² \\ Universitas Borobudur, Jakarta, Indonesia ${ }^{1,2}$
}

\begin{abstract}
This study provides a perspective of civil law studies on the impact of divorce on children. By using normative juridical research methods, through literature studies as a data collection tool, it was found that children are the subject of legal studies in civil divorce decisions. In Civil terms, parental power over an immature child ends when a divorce occurs and is replaced by guardianship. In the maintenance of life, parents are responsible for paying the costs of maintaining and educating the child, adjusted to the child's needs and the provider's earning.
\end{abstract}

Keywords: Children; Divorce; Civil Law

\section{Introduction}

To build a great nation, people who are smart and have good character are needed. To achieve this, of course, well education and character should be applied from an early age to the nation's children. Children are one of the assets to advance the State. The development of the era makes the mindset and manners of children decrease. In this day and age, not a few cases of children as actors of crime. The rate of child delinquency is increasing from year to year due to several factors. Factors that cause child delinquency so that children are trapped in criminal cases and ultimately have to face the law include lack of parental attention, circumstances that require children to meet the needs of life, or even the search for identity.[1]

One of the causes of children committing crimes is divorce. Neglected children will make less attention, affection and end up with criminal acts. Marriage is a sacred thing that every husband and wife always craves the creation of a sakinah, mawaddah, and warahmah household, or in Javanese terms, it is often called calm and peaceful.[2] When the household is in a state of harmony, generally the joint property acts as a complement to happiness. However, if the family experiences an unstable condition, the possibility of disputes and quarrels is quite large. Frequently, if the dispute cannot be resolved (out of control), the chances of household conditions reaching the peak of the conflict will lead to the dissolution of the marriage are even higher. If a divorce occurs, it will have consequences for the people involved in one household, in which legal consequences will be highlighted. The legal outcomes of this divorce are also related to children and assets during the marriage. Take a look at this issue. It is because of the cultural problems of the people who still consider marriage to be sacred, sacred, great, and eternal. That means that every married couple must 
maintain their chastity, from the marriage process to managing their household, since it is sacred, discussing property issues before and during the marriage is taboo.

However, in reality, the husband and wife only questioned the distribution of this common property after the divorce decision from the court, and usually, in the court process, there was often a commotion about the distribution of family assets so that this condition further complicates the divorce process. That is because they (prospective husband and wife) do not think, at all, about the problem of this common property. On the other hand, problems often occur regarding child custody. Parental divorce results in children being contested for supervision, affected in the loss of a parental figure.

Legally-formally in the laws and regulations in the country, both in Law Number 1 of 1974 concerning Marriage, [3] the Civil Code (KUHPerdata), regarding child custody. In this regard, this article provides a review related to the impact of divorce on children from the civil law perspective.

\section{Method}

This paper utilizes a subjective methodology, with a regularizing juridical methodology (Legal Research).[4] The kind of regulating juridical examination is research led by looking at library materials or optional information. The standardizing legitimate examination or writing remembers research for lawful standards, research on lawful systematics, research on degrees of vertical and level synchronization, relative law, and lawful history.[5]

\section{Discussion}

The Republic of Indonesia as a protected State has a constitution, the 1945 Constitution. In the Constitution, uniformity under the steady gaze of the law is managed, specifically in Article 27 that peruses: All residents are equivalent under the watchful eye of the law and the public authority and are obliged to maintain law and government with no exemption; Every resident has the privilege to work and a good living for mankind.[6]

In 2002 a few articles of the 1945 Constitution were revised, in particular Article $28 \mathrm{D}$ Paragraph (1) which peruses: "Everybody has the option to acknowledgment, ensures, insurance, and reasonable legitimate conviction and equivalent treatment under the steady gaze of the law," and Article 281 Paragraph (2), which expresses that "Everybody has the option to be free and has the privilege to security against such biased treatment." [6]

The two articles show that all Indonesian citizens, both men, and women, are equal before the law and are guaranteed by the above explanation, legally speaking, there is no gender discrimination or injustice for women in Indonesia. However, at the level of implementing the 1945 Constitution, women experience gender injustice in legal matters.[7] It happens for various reasons, for example, there are no instructions for implementing the principle of equality between women and men before the law. Furthermore, the implementation level of the constitution will be explained in the family law regarding marriage.

Marriage is an interpersonal relationship that including in family law in civil law. According to the Civil Code (KUHPerdata), the definition of marriage in Article 26: "The law views marriage only in civil relations. Marriage, according to the Civil Code that from a civil point of view and is only seen from legal institutions, does not depend on religion and biologist from husband and wife. Since the enactment of Law No. 1 of 1974 concerning 
Marriage. On January 2, 1974, a law was created to regulate the family sector which has been coveted for so long. Thus, Indonesian citizens, both male and female, have had a juridical basis to obtain legal protection, as contained in the 1945 Constitution article 27 paragraph 1 and Law no. 1 year regarding Marriage.

Before the birth of Law No. 1 of 1974 that regulates marriage, many household problems occur because of arbitrary treatment by the husband. For example, if the husband wants a divorce in his household, it can happen easily. The wives cannot resist the arbitrariness of the husband and must accept the talaq handed down to him. After the enactment of Law No. 1 of 1974 on Marriage, then divorce can only occur before a court of law. The fall of a divorce decision can take effect after a divorce application is filed with the reasons and the court has tried to reconcile both parties but to no avail. Marriage laws that legislated among other things to prevent arbitrary divorce from husbands. [8]

About divorce, there is a lot of data showing that the number is increasing. The divorce rate is getting higher, there is even a tendency for the wife to file for divorce, which is bigger than the husband. The phenomenon of increasing divorce is a symptom of the increasing freedom and independence of women, while men (husbands) still maintain their dominance over their wives. According to research, a wife who experiences divorce will automatically become the head of the household and also as a breadwinner for herself and for the education costs of the children she cares for. If the ex-husband does not provide a living, the problems faced by the wife as the head of the household are heavy enough. In addition to socioculturally, women are considered as the second person after men, women are also fully responsible for the survival of the household, as housewives, breadwinners, and citizens of the community. [9]. The Law No. 1 of 1974 On Marriage also adheres to the following principles or principles [10] :

a. The reason for marriage is to shape a glad and timeless family.

b. Marriage is legitimate in case it is completed by the law of his religion and conviction.

c. Marriages must be registered according to the laws and regulations.

d. d. Prospective husband and wife must have matured body and soul to get married.

e. The marriage is based on open monogamy.

f. The general limit for marriage is 19 years for men and 16 years for women.

g. Divorce is complicated and must be done before the court.

h. The privileges and status of a couple are equivalent.

The problem of caring for children as a result of their parents' divorce according to Law Number 1 of 1974 Article 41 states that: [11]

a. Both mother and father are as yet obliged to keep up with and instruct their youngsters, exclusively dependent on the interests of the kid; when there is a debate in regards to the control of kids the Court gives its choice;

b. The father is answerable for all expenses of upkeep and schooling required by the kid; if the dad can't satisfy these commitments. The Court might discover that the mother partakes in the expenses;

c. The Court can oblige the ex to give everyday costs or potentially decide a commitment for the ex

From the provisions of Article 41 above is expressly explained that the right to care for children as a divorce result is the responsibility of both parents. Unless there is a conflict, the court decides to whom the right to care for the child is given. Furthermore, in providing a living for living expenses, health, and education until the child is married or independent, it is the responsibility of the husband or father. In addition, the husband is also required to provide a living for his ex-wife as long as the wife is still a widow or not married to someone else. 
A legal child (Wetting Kind) is a child who is considered to be born from a legal marriage between his father and mother. The certainty that a child is his father's child is hard to come by. According to Article 257 Paragraph (1) BW, it is explained that a husband can deny that the child born to his wife is not legal, provided that if the husband can prove that from 180 days to 300 days before the child is born it is impossible to have intercourse with his wife, because of not gathering or from other reasons. The provision of 180 days and 300 days is considered the maximum grace period for pregnancy. The next provisions regulated children who are under guardianship, namely: [10]

a. Legitimate child of both parents whose authority as parents has been revoked.

b. Legal child whose parents have divorced.

The right to the situation of youngsters is directed in Articles 42.43 and 44 of UUP No. 1 of 1974 on Marriage. A genuine youngster is a kid brought into the world in or because of a legitimate marriage. Kids conceived illegitimately have just a common relationship with the mother and her mom's family. A spouse can keep the lawfulness from getting a youngster brought into the world to his better half in the event that he can demonstrate that his significant other has submitted infidelity and that the kid is the aftereffect of that infidelity. The court can choose whether or not the youngster is lawful in line with an invested individual.

In Marriage Law No. 1 of 1974, a legitimate child is a child born in or as a result of a legal marriage. So if a woman has become pregnant because of committing adultery with another person, then she legally marries a man who is not the giver of seeds in the woman's womb, then if the child is born, the child is the legal child of the woman's marriage to that man.

According to Hilman Hadikusuma regarding Marriage in Islamic law, it is said that the marriage bond, will give rise to rights and obligations between parents and their children. A father is burdened with the duty of caring for and educating his children, while a mother is helpful, the mother is only obliged to breastfeed and care for her children. [12] The care and maintenance of a child are the mother's obligation, while the right to education for a child is obligated to both parents. These rights and obligations are imposed on each parent, either

during the marriage or if the marriage has been terminated. According to the Civil Code, the rights and obligations of parents to children are legal relations and liabilities at a certain age, until children born in marriage bonds reach a certain age, which is called adulthood.[13]

Provisions regarding the position of children have been regulated in the Marriage Law Number 1 of 1974 in Chapter XI articles 42 to 43.[3] The problem of this child's position, especially concerning his father's side. As for the mother in general, it can be said that it is not too difficult to find out who the mother of the child born is. Finding out who the father of a child is complicated. For a mother, the child is considered to always have a legal relationship with his mother. With the father, the child is not like that. The child has no legal relationship with the father who has bred him.

\section{Conclusion}

The obligation to take care of children (alimentation) due to divorce has obligations in the care that must be given to their children. The existing legislation in Indonesia facilitates legal protection for children who are victims of divorce to choose to live and settle down with their father or mother. However, obligations regarding life, school, and living are the responsibility of his parents. All the needs needed by children who are victims of divorce are fully the 
responsibility of both parents according to their abilities. All violations caused by parental negligence can be filed before the law following the provisions of the applicable laws.

\section{References}

[1] D. N. Sari, "UPAYA PREVENTIF GURU KRISTEN DALAM MENGHADAPI DEGRADASI MORAL ANAK [PREVENTIVE EFFORTS OF CHRISTIAN TEACHERS IN FACING CHILDREN'S MORAL DEGRADATION]," VISIO DEI J. Teol. Kristen, vol. 1, no. 1, pp. 79-100, 2019.

[2] F. J. Nugroho and D. N. Sari, "Kawruh Pamomong: Pendidikan Karakter Kristiani Berbasis Kearifan Lokal [Kawruh Pamomong: Christian Character Education Based on Local Wisdom ]," Kur. J. Teol. dan Pendidik. Agama Kristen, vol. 6, no. 2, p. 289, 2020, [Online]. Available: http://www.sttpb.ac.id/e-journal/index.php/kurios.

[3] Law of the Republic of Indonesia Number 1 of 1974 concerning Marriage and the Compilation of Islamic Law, 5th Printed. Bandung: Citra Umbara, 2010.

[4] I. M. P. Diantha, "Metodologi Penelitian Hukum Normatif [Normative Legal Research Methodology]," Teor. Metodol. Penelit. a., 2017.

[5] D. L. Sonata, "METODE PENELITIAN HUKUM NORMATIF DAN EMPIRIS: KARAKTERISTIK KHAS DARI METODE MENELITI HUKUM [NORMATIVE AND EMPIRICAL LEGAL RESEARCH METHODS: DIFFERENT CHARACTERISTICS OF LEGAL RESEARCH METHODS]," FIAT JUSTISIAJurnal Ilmu Huk., 2015, doi: 10.25041/fiatjustisia.v8no1.283.

[6] P. M. Marzuki, Introduction to Law. Jakarta: Kencana Prenadamedia Group, 2006.

[7] S. Soekanto, Introduction to Legal Research. Jakarta: UI Press, 2012.

[8] M. Ashsubli, " Marriage Law in the Plurality of Religious Laws (Judicial Review of Interfaith Marriage Articles)," J. CITA Huk., vol. 3, no. 2, pp. 289-302, Jan. 2016, doi: 10.15408/jch.v2i2.2319.

[9] B. Basuni and R. Sara, "Community-Based Education as A Form of Education Fulfilment for Children in Conflict with the Law (Abh)," 2021, doi: 10.4108/eai.6-32021.2306871.

[10] W. Darmabrata, Review of Law No. 1 of 1974 concerning Marriage and its Laws and Implementing Regulations. Jakarta: Gitama Jaya, 2003.

[11] D. David and Z. Fakrulloh, "Analysis of the Traditional Marriage of the Dayak Kadorih Tribe in the Perspective of Law Number 1 of 1974 Concerning Marriage," 2021, doi: 10.4108/eai.6-3-2021.2306410.

[12] H. Hadikusuma, Indonesian Marriage Law. Bandung: Mandar Maju, 1990.

[13] A. Sosroatmodjo and A. W. Aulawi, Indonesian Marriage Law. Jakarta: Bulan Bintang, 1978. 